\title{
The Implementation of Non-Smoking Area (KTR) in Campus University of Muhammadiyah Aceh 2017
}

\author{
Vera Nazhira Arifin ${ }^{1 *}$, Dedi Andria ${ }^{1}$, Hayatun Nufus ${ }^{1}$, Meutia Zahara ${ }^{2,3}$, \\ Sutri Helfianti ${ }^{4}$, Surna Lastri ${ }^{5}$
}

\author{
${ }^{1}$ Faculty of Public Health, University Muhammadiyah Aceh, Banda Aceh, Indonesia \\ ${ }^{2}$ Postgraduate Program of Public Health, University Muhammadiyah Aceh, Banda Aceh, Indonesia \\ ${ }^{3}$ Department of Biology, Islamic Faculty, University Muhammadiyah Aceh, Banda Aceh, Indonesia \\ ${ }^{4}$ Faculty of Law, University Muhammadiyah Aceh, Banda Aceh, Indonesia \\ ${ }^{5}$ Faculty of Economic, University Muhammadiyah Aceh, Banda Aceh, Indonesia
}

Corresponding author. Email: veranazhira13@gmail.com

\begin{abstract}
Based on the Public Health Development Index (IPKM) data 2016, the prevalence rate of tobacco consumption in Aceh province is considered high at $36.01 \%$ and still below the standard rate of Indonesian tobacco consumption of $32.09 \%$. Various efforts have been made by non-smoking areas (KTR) described in Law no. 36 Year 2009 and Joint Decree of the Minister of Health and Minister of Home Affairs Number 188 / Menkes / PB / I / 2011, PP Number 109 of 2013. The objective of this research is to find out the implementation of NonSmoking Area (KTR) in Campus Area of University Muhammadiyah Aceh. The research method is analytic descriptive with cross-sectional design. The data were collected by interview using questionnaire. The Result of research shows that $60.27 \%$ of students answered there is no policy of Non-Smoking Area, $63.01 \%$ of Student aware of Non-Smoking Area Policy, 60,27\% there are punishment applied to student who smoke, 58,9\% there are socialization Non-Smoking Area, 60,27\% there was lack of role of Student Executive Board related to nonsmoking area and $89,04 \%$ availability of smoking area. The result of bivariate analysis shows that there is a relation between regulation $(0,002)$ and punishment $(0,007)$ to non-smoking area policy, while socialization $(0,311)$, Student Executive Board $(0,815)$ and smoking area $(0,367)$ have no relation with non-smoking area policy in University of Muhammadiyah Aceh. The research shows that from 5 independent variables, there are only two independent variables, namely Punishment and regulation which is significantly related to KTR implementation in UNMUHA environment. Meanwhile, the socialization of KTR, the role of Student Executive Board and Smoking Area is not related to the implementation of KTR in UNMUHA environment.
\end{abstract}

Keywords: implementation of Non-smoking area (KTR), UNMUHA, punishment, regulation, socialization

\section{INTRODUCTION}

WHO reported that there are 1.2 billion people who use tobacco products worldwide and 800 million of them are in developing countries. Indonesia is currently ranked 3rd with the largest number of smokers in the world after China and India [1]. In 2007, Indonesia was ranked as the 5th largest cigarette consumer after China, the United States, Russia, and Japan. The increasing amount of cigarette consumption has an impact on the higher burden of diseases caused by smoking and the increase in mortality rates. By 2030 it is estimated that the death rate of smokers in the world will reach 10 million people and $70 \%$ of them come from developing countries [2]. Nowadays, $50 \%$ of deaths due to smoking occur in developing countries. If this trend continues, around 650 million people will be killed by cigarettes, of which half are of productive age and will potentially lose their lives (life loss) by 20 to 25 years [2]. Meanwhile, in developed countries, the mortality rate due to tobacco consumption actually declined from 2.8 million people to 1.6 million people in the same period [1].

Referring to Baseline Health Research, the prevalence of smoking for the age group > 15 years in 2007 was $34.2 \%$, in 2010 it was $34.7 \%$, and the smoking rate increased in 2013 by $36.3 \%$. Compared to the Global Adults Tobacco 
Survey (GATS) study of population aged > 15 years, the proportion of male smokers was $67.0 \%$ and the 2013 Baseline Health Research (Riskesdas) was $64.9 \%$, whereas for women according to the Global Adults Tobacco Survey (GATS) was $2.7 \%$ [2].

In Indonesia, the problem related to cigarettes raises the pro and contra among the society. The government faces a dilemma in dealing with problem of smoking, between healthy and economic. The cigarettes make is significant contribution to government revenue through tax, Value Added Tax (VAT) and Income tax (PPh) [10]. Indonesia is not only a consumer of cigarettes but also a producer of cigarettes, which involves three big tobacco companies that dominate more than $70 \%$ of the market share $[12,13]$. The number of tobacco consumption at productive age 17 years old above in Indonesia is increasing year by year, the overall number of smoker in 2013 increased until 12.3 times from 1995 [11].

The university years are an important life phase for every student during which they develop and engage in risky behaviours such as smoking. Smoking therefore is an important public-health problem among university students Muhammadiyah University of Aceh is one of the three universities in Aceh that has implemented a No Smoking Area (KTR) on campus. The problem found at UNMUHA related to the implementation of KTR is that there are still many students who smoke in the campus environment, this is still a lack of control / enforcement efforts towards the KTR area. Therefore the formulation of the problem in this research is to analyze how the regulation of Non-Smoking Area (KTR) policies in the campus environment of the University of Muhammadiyah Aceh. The purpose of this reseach is to assess the implementation of Non-Smoking Area (KTR) in Campus Area of University Muhammadiyah Aceh.

\section{METHOD}

This research is a descriptive-analytic study with CrossSectional design, in which the research is being conducted at one time and once, there is no follow-up, to look for the relationship between independent variables (risk factors) with dependent variables (effects) (Notoatmodjo, 2010). This research is conducted within the University of Muhammadiyah Aceh's environment. In addition, the population in this study is all students of the University of Muhammadiyah Aceh with a total of 3,352 students. The number of samples in this study was 97 samples. The instrument of the study using questionnaire and the study conducted from August 10- September 30 2017. Sample size calculation using Slovin formula. The sampling selected as a sample is done using a proportionate stratified random sampling technique. The statistical test used is chisquare test and logistic regression by using STATA 13.

\section{RESULTS AND DISCUSSION}

The research outcome on 97 respondents from the University of Muhammadiyah Aceh students in October 2016 on the policy of no-smoking areas within the campus area has been outlined in the form of univariate and bivariate tables. The data conducted using univariate analysis in this study are in the form of no-smoking areas, regulations, punishment, socialization, the role of the Student Executive Board (BEM), and smoking areas for students at the University of Muhammadiyah Aceh. The results of the univariate and bivariate analysis could be seen from the following table:

Table 1. Univariate Analysis

\begin{tabular}{|c|c|c|c|}
\hline Variable & Category & n (75) & \multirow{7}{*}{$\begin{array}{c}\% \\
39,73 \\
60,27 \\
63,01 \\
36,99 \\
60,27 \\
39,73 \\
58,9 \\
41,1 \\
39,73 \\
60,27 \\
89,04 \\
10,96\end{array}$} \\
\hline Non-Smoking Area & \multirow{6}{*}{$\begin{array}{l}\text { Available } \\
\text { Not available } \\
\text { Available } \\
\text { Not available } \\
\text { Available } \\
\text { Not available } \\
\text { Available } \\
\text { Not available } \\
\text { Have a role } \\
\text { No role } \\
\text { Available } \\
\text { Not available }\end{array}$} & $\begin{array}{l}29 \\
44\end{array}$ & \\
\hline Regulation & & $\begin{array}{l}46 \\
27 \\
\end{array}$ & \\
\hline Punishment & & $\begin{array}{l}44 \\
29\end{array}$ & \\
\hline Sosialization & & $\begin{array}{r}3 \\
30 \\
\end{array}$ & \\
\hline Role of BEM & & $\begin{array}{l}29 \\
44 \\
\end{array}$ & \\
\hline Smoking Area & & $\begin{array}{r}65 \\
8\end{array}$ & \\
\hline
\end{tabular}

Based on table 1 above, it could be seen that students who stated: "the existence of a no-smoking areas policy" at the University of Muhammadiyah Aceh's environment were $39.73 \%$. Meanwhile, respondents who stated that "there was no smoking policy" in the environment of the University of Muhammadiyah Aceh were $60.27 \%$. Table 1 , shows that students who stated: "the existence of regulations on Non-Smoking Areas" at the University of Muhammadiyah Aceh were higher at $63.01 \%$ compared to students who stated that "there were no regulations" on Non-Smoking Areas at the University of Muhammadiyah Aceh, 36.99\% and students who stated: "the existence of punishments" applied at Muhammadiyah University of Aceh for smokers was higher at $60.27 \%$ compared to students who stated: "no punishment" applied at Muhammadiyah University of Aceh for smokers at $39.73 \%$. Therefore students who stated: "there is a socialization" conducted at the University of Muhammadiyah Aceh about cigarettes were higher at $58.9 \%$ in comparison with students who stated: "there was no socialization" carried out at Muhammadiyah University of Aceh at $41.1 \%$.

The establisment of a non-smoking area is an effort to facilitate the human rights for healthy needs including in the educational area [8]. A non-smoking area is the responsible of all society components in the country, such as individuals, communities, government and non- 
government institutions, for the purpose of health protections for future generations and society. Joint commitments from cross sectors and various elements will greatly influence the success of the non-smoking area [9]. It has been discovered that students who said: "there was no role of the Student Executive Board (BEM)" in the implementation of the No-Smoking Areas was $60.27 \%$ compared to students who said: "The Student Executive Board has a role" in the implementation of the No-Smoking Areas by $39.73 \%$. Based on Table 4.6, it reveals that students who stated: "there was a smoking area provided" by the university were higher at $89.04 \%$ compared to students who stated: "there was no-smoking area provided" by the university which was $10.96 \%$. To find out the relationship between the dependent variable and the independent variable, a statistical test was performed using the Chi-Square test and declared significant if P-Value $<0.05$.

Table 2. Bivariate Analysis

\begin{tabular}{|c|c|c|c|c|c|c|}
\hline \multirow{3}{*}{ Variable } & \multirow{3}{*}{$\begin{array}{c}\text { Sub } \\
\text { Variable }\end{array}$} & \multicolumn{4}{|c|}{ Non-Smoking Area } & \multirow{3}{*}{$\begin{array}{c}p \\
\text { Value }\end{array}$} \\
\hline & & \multicolumn{2}{|c|}{ Available } & \multicolumn{2}{|c|}{ Not Available } & \\
\hline & & $\mathbf{N}$ & $\%$ & $N$ & $\%$ & \\
\hline \multirow[t]{2}{*}{ Regulation } & Available & 12 & 26,09 & 34 & 73,91 & \\
\hline & $\begin{array}{l}\text { Not } \\
\text { available }\end{array}$ & 17 & 62,96 & 10 & 37,04 & 0,002 \\
\hline \multirow[t]{2}{*}{ Punishment } & Available & 12 & 27,27 & 32 & 72,73 & \\
\hline & $\begin{array}{l}\text { Not } \\
\text { available }\end{array}$ & 17 & 58,62 & 12 & 41,38 & 0,007 \\
\hline \multirow{2}{*}{ Sosialization } & Available & 15 & 34,88 & 28 & 65,12 & \\
\hline & $\begin{array}{l}\text { Not } \\
\text { available }\end{array}$ & 14 & 46,67 & 16 & 53,33 & 0,311 \\
\hline \multirow[t]{2}{*}{ Role of BEM } & Have a & 12 & 41,38 & 17 & 58,62 & \\
\hline & $\begin{array}{l}\text { role } \\
\text { No role }\end{array}$ & 17 & 38,73 & 27 & 61,36 & 0,815 \\
\hline \multirow[t]{2}{*}{ Smoking Area } & Available & 12 & 41,38 & 17 & 58,62 & \\
\hline & $\begin{array}{c}\text { Not } \\
\text { available }\end{array}$ & 17 & 38,64 & 27 & 61,36 & 0,367 \\
\hline
\end{tabular}

Table 2, shows that the scale of respondents who stated: "the existence of no-smoking area" was higher than respondents who stated: "no regulations" as much as $62.96 \%$ compared to respondents who stated "there were regulations", $26.09 \%$. While the percentage of respondents who stated: "there were no-smoking areas" was higher than respondents who stated: "there were regulations" as much as $73.91 \%$ compared to respondents who stated: "no regulations" which was $37.04 \%$. The statistical test results using the chi-square test obtained $p$-value $=0.002$, which means that there is a significant relationship between regulation and the implementation of the "no-smoking area" in the environment of the University of Muhammadiyah Aceh.

Based on Table 2, it reveals the proportion of the number of respondents who stated: "there were no-smoking areas" was higher in respondents who said: "there were no punishments" was as much as $58.62 \%$ in comparison with respondents who stated: "there were punishments" which was $27.27 \%$. Whereas the scale of respondents who stated: "there were no-smoking areas" was higher than respondents who stated: "there were punishments" of $72.73 \%$ compared to respondents who stated: "there were no punishments" of $41.38 \%$. The statistical test results using the chi-square test get the p-value $=0.007$, which means that there is a significant relationship between punishments and the implementation of nosmoking areas in the University of Muhammadiyah Aceh.

According to the table above the proportion of respondents who stated "there were no smoking areas" was higher for respondents who stated "there were no socializations" conducted by the university as much as $46.67 \%$ compared to respondents who stated "there were socializations carried out by the university" which is $34.88 \%$. Whereas the scale of respondents who stated "there were no-smoking areas" was higher than respondents who stated "there were socializations carried out by the university" as much as $65.12 \%$ compared to respondents who said: "there were no socializations carried out by the university" which was $53.33 \%$. The statistical test results using the chi-square test obtained $\mathrm{p}$-value $=0.311$, which means there is no significant relationship between socialization and the implementation of no-smoking areas in the University of Muhammadiyah Aceh.

Therefore, that the scale of respondents who stated: "the existence of no-smoking areas" was higher than respondents who stated: "the role of the Student Executive Board" was $41.38 \%$ compared to respondents who stated: "the absence of the role of the Student Executive Board", 38, 64\%. While the percentage comparison of respondents who stated: "there is a nosmoking area" was higher in respondents who stated: "there was no role of the Student Executive Board" as much as $61.36 \%$ compared to respondents who stated: "there was a role of the Student Executive Board", $58.62 \%$. The results of statistical tests using the chisquare test have found that the $\mathrm{p}$-value $=0.815$, which means there is no significant relationship between the role of the Student Executive Board and "the implementation of a no-smoking area" in the area of the University of Muhammadiyah Aceh. It has been shown that the proportion of respondents who stated: "there was a no-smoking area" was higher in respondents who stated: "there was a smoking area" as much as $41.54 \%$ compared to respondents who said: "there was a nosmoking area" was $25 \%$. Whereas the proportion of respondents who stated: "there was a no-smoking area" was higher in respondents who stated: "no-smoking area" was $75 \%$ compared to respondents who stated: "there was a smoking area", 58.46\%. The results of statistical tests using the chi-square test have found that the value of $p$-value $=0.367$, which means "there is no significant relationship" between smoking areas and the implementation of no-smoking areas in the area of the University of Muhammadiyah Aceh. 


\section{Discussion}

The results of the study have revealed the proportion of respondents who stated that there was a "no-smoking area" was higher than respondents who stated: "there were no regulations" as much as $62.96 \%$ compared to respondents who stated: "there were regulations" as much as $26.09 \%$. Meanwhile, the proportion of respondents who stated; "there was a no-smoking area" was higher than respondents who stated: "there were regulations" which showed $73.91 \%$ in comparison with respondents who stated: "no regulations", $37.04 \%$. The results of statistical tests using the chi-square test have obtained the value of $\mathrm{p}$-value $=$ 0.002 , which means that there is a significant relationship between regulation and the implementation of no-smoking areas within the University of Muhammadiyah Aceh. Some research results have stated the importance of applying "nosmoking areas" to smoking behavior. The results of studies on the effectiveness of the application of regional regulations related to the "no-smoking area" by Nizwardi Azka (2013) explains that there is evidently a trend of decreasing smokers by $59 \%$ in public places [4]. A similar study conducted by Yayi Suryo (2009) states that the application of a smoke-free campus could actually reduce the number of students who smoke regularly [5] indeed, this policy limits the movement of active smokers so that they might provide protection to passive smokers.

\section{The Relationship of Punishment (Sanction) With the Implementation of No-Smoking Areas}

Based on the results of the study, the ratio of respondents who stated that a "no-smoking area" was higher in respondents who stated: "there were no punishments" as much as $58.62 \%$ compared to respondents who said: "there were punishments", $27.27 \%$. Whereas the proportion of respondents who stated: "there were no smoking areas" was higher than respondents who stated "there were smoking areas" which showed $72.73 \%$ compared to respondents who stated: "there were no punishments", $41.38 \%$. The statistical test results using the chi-square test obtained $\mathrm{p}$-value $=$ 0.007 , which means that there is a significant relationship between punishment and the implementation of a nosmoking area within the University of Muhammadiyah Aceh. The existence of strict sanctions might seem very beneficial to limit the space for active smokers. This is as expressed by Purwanto and Sulistyastuti (2012), that the existence of areas without smoking and sanctions could limit the space for active smokers. This is sure to make smokers could reduce the frequency of smoking in one day. In addition, the existence of a no-smoking area could also protect the passive smokers [6].

The Relationship of Socialization with the Implementation of No-Smoking Areas

The results of the study have discovered that the proportion of respondents who have stated that there is a "no-smoking area" is higher than respondents who stated: "there is no socialization carried out by the university" as much as $46.67 \%$ compared to respondents who said: "there was", $34.88 \%$. In the meantime, the proportion of respondents who stated that there was no "no-smoking area" was higher than respondents who stated: "there was socialization carried out by the university" which showed $65.12 \%$ in comparison with respondents who stated: "none" was $53.33 \%$. The results of statistical tests that use the chisquare test have obtained the value of $p$-value $=0.311$, which means there is no significant relationship between socialization and the implementation of no-smoking areas within the University of Muhammadiyah Aceh.

The outcome of Azkha's research (2013) revealed that the socialization regarding the implementation of no-smoking areas in the city of Padang has been carried out through various mass media such as TV, radio, and dialogue [4]. The other research displayed that the leaflet was influential ( $\mathrm{p}=$ 0,000 ) in increasing knowledge about the dangers of smoking in students of SDN 78 Sabrang Lor Mojosongo, Surakarta [7].

The Relationship between the Role of the Student Executive Board (BEM) and the Implementation of the No-Smoking Areas

The results of the study have been successful to uncover the proportion of respondents who have stated the existence of "no-smoking areas" is higher in respondents who stated: "there is a role of the Student Executive Board", 41.38\% compared to respondents who stated: "none" as much as $38.64 \%$. Meanwhile, the scale of respondents who had stated: "no-smoking area" was higher than respondents who stated: "there was no role of the Student Executive Board" which showed $61.36 \%$ in comparison with respondents who said: "there was a role of the Student Executive Board" as much as $58.62 \%$. The results of statistical tests using the chi-square test have obtained $\mathrm{p}$-value $=0.815$, which means there is no significant relationship between the role of BEM with the implementation of no-smoking areas within the University of Muhammadiyah Aceh.

The Relationship between Smoking Areas and the Implementation of No-Smoking Areas

Based on the outcome of the study, the proportion of respondents who stated: "there was no-smoking area" was higher in respondents who stated: "there was a smoking area" as much as $41.54 \%$ compared to respondents who stated: "no-smoking area" was $25 \%$. While the percentage of respondents who stated: "there was no-smoking area" was higher than respondents who stated: "no-smoking area", 75\% in comparison with respondents who stated: "there was a smoking area" as much as $58.46 \%$. The results of the statistical tests using the chi-square test have obtained the $\mathrm{p}$-value $=0.367$, which means there is no significant relationship between a smoking area and the implementation of a no-smoking area within the University of Muhammadiyah Aceh.

\section{CONCLUSION}

In conclusion, the socialization of the No-Smoking Area, the role of the Student Executive Board and the presence of the Smoking Area are not related to the implementation of the No-Smoking Area in the UNMUHA environment. This means that the presence or absence of the No-Smoking Area 
[7] Rahmadi, et al,. Hubungan Pengetahuan, Sikap Terhadap Rokok dengan Kebiasaan Merokok Siswa di Kota Padang. Jurnal kesehatan Andalas. 2013; 2 [8] Winengan. Implementasi Kebijakan Kawasan Tanpa Rokok di Kota Mataram. diakses juni 2017

[8] Qanun Kota Banda Aceh Tahun 2016 Tentang Kawasan tanpa Rokok

[9] Juanita. Kebijakan Kawasan Tanpa Rokok: Peluang dan Hambatan Smoking Free Area Policy; Opportunites and Treat (Online Elektronik). Diakses 2 Juni 2012. Jurnal Kebijakan Kesehatan Indonesia. 2012

\section{ACKNOWLEDGMENT}

The authors would like to thank to Abdul Malik Badeges, Luthfi Nanda Perdana, Muhammad and Tiya lestari for supporting and finishing the research paper.

\section{REFERENCES}

[1] WHO [homepage on the internet]. 2015. A Report: consumption and cigarette prevalence. [updated 2015; cited 2016 May 1]. Available from:http// www.ino.searo.who.int/

[2] Kementrian Kesehatan Pusat Promosi Kesehatan. Pedoman Pengembangan Kawasan Tanpa Rokok. Kemenkes RI, Jakarta; 2015.

[3] Supriyadi. Kawasan Tanpa Rokok Sebagai Perlindungan Masyarakat Terhadap Paparan Asap Rokok Untuk Mencegah Penyakit Terkait Rokok [skripsi]. Semarang: Universitas Dian Nuswantoro; 2014.

[4] Azka, Nizwandi. Studi Efektivitas Penerapan Perda Kota Tentang Kawasan Tanpa Rokok (KTR) dalam Upaya Menurunkan Perokok Aktif di Sumatera Berat Tahun 2013. Jurnal Kebijakan Kesehatan Indonesia. 2013; 2 (4).

[5] Yayi Surya, Nawi Ng, Retna Siwi Padmawati. Kawasan Tanpa Rokok Sebagai Alternatif Pengendalian Tembakau Studi Efektifitas Penerapan Kebijakan Kampus Bebas Rokok Terhadap Prilaku dan Status Merokok Mahasiswa di Fakultas Kedokteran UGM, Yogyakarta. Jurnal Manajemen Pelayanan Kesehatan. 2009; 12 (4).

[6] Purwanto E.A dan D.R. Sulistyastuti. Implementasi Kebijakan Publik. Gava Media, Yogyakarta; 2012.
[10] Surbakti, P. Indonesia's National SocioEconomic Survey: a continual data source for analysis on welfare development. Central Bureau of Statistics; Ministry of Health (2007). Basic Health Survey. Jakarta: Badan Penelitian dan Pengembangan Kesehatan Ministry of Health Republic of Indonesia; and Ministry of Health (2013). Basic Health Survey. Jakarta: Badan Penelitian dan Pengembangan Kesehatan Ministry of Health Republic of Indonesia. 2013

[11] Yogatama and Krisna, B. Cigarette export in 2015 can reach USD 1.1 billion (Ekspor rokok 2015 bisa mencapai US\$ 1,1 miliar). Editor: Uji Agung Santosa. www.kontan.co.id. 2014. Download from http: //industri.kontan.co.id/news/ekspor-rokok2015-bisa-mencapai-us-11-miliar. 2014

[12] Rahmayanti, K. P. Local Government Commitment to the Smoke-Free Policy in Indonesia. Conference Paper; The 3rd IMOPH \& the 1st YSSOPH, Knee Life Sciences. 2019. 